\title{
The influence of inorganic nitrogen fertilizer forms on micronutrient retranslocation and accumulation in grains of winter wheat
}

\author{
Nunun Barunawati, Ricardo F. Hettwer Giehl, Bernhard Bauer and Nicolaus von Wirén * \\ Molecular Plant Nutrition, Department of Physiology and Cell Biology, Leibniz Institute of Plant Genetics and Crop Plant Research, Gatersleben, Germany
}

\section{Edited by:}

Jan K. Schjoerring, University of

Copenhagen, Denmark

\section{Reviewed by:}

Michael A. Grusak, USDA-ARS

Children's Nutrition Research

Center, USA

Ümit B. Kutman, Sabanci University,

Turkey

\section{*Correspondence:}

Nicolaus von Wirén, Molecular Plant Nutrition, Department of Physiology and Cell Biology, Leibniz Institute of

Plant Genetics and Crop Plant

Research, Corrensstrasse, 3,

D-06466, Gatersleben, Germany

e-mail: vonwiren@ipk-

gatersleben.de
The fortification of cereal grains with metal micronutrients is a major target to combat human malnutrition of $\mathrm{Fe}$ and $\mathrm{Zn}$. Based on recent studies showing that $\mathrm{N}$ fertilization can promote $\mathrm{Fe}$ and $\mathrm{Zn}$ accumulation in cereal grains, we investigated here the influence of nitrate- or ammonium-based $\mathrm{N}$ fertilization on the accumulation of $\mathrm{Fe}, \mathrm{Zn}$, and $\mathrm{Cu}$ as well as metal chelator pools in flag leaves and grains of winter wheat. Fertilization with either $\mathrm{N}$ form increased the concentrations of $\mathrm{N}$ and of the metal chelator nicotianamine (NA) in green leaves, while 2'-deoxymugineic acid (DMA) remained unaffected. Despite the differential response to $N$ fertilization of $N A$ and DMA levels in flag leaves, $N$ fertilization remained without any significant effect on the net export of these metals during flag leaf senescence, which accounted for approximately one third of the total $\mathrm{Fe}, \mathrm{Zn}$, or $\mathrm{Cu}$ content in leaves. The significant increase in the accumulation of $\mathrm{Fe}, \mathrm{Zn}$, and $\mathrm{Cu}$ found in the grains of primarily ammonium-fertilized plants was unrelated to the extent of metal retranslocation from flag leaves. These results indicate that an increased $\mathrm{N}$ nutritional status of flag leaves promotes the accumulation of $\mathrm{Fe}, \mathrm{Zn}$, and $\mathrm{Cu}$ in flag leaves, which is accompanied by an increased pool of NA but not of DMA. With regard to the far higher concentrations of DMA relative to NA in leaves and leaf exudates, DMA may be more relevant for the mobilization and retranslocation of these metals in high-yielding wheat production.

\section{Keywords: biofortification, phytosiderophores, ammonium, nitrate, iron, zinc}

\section{INTRODUCTION}

The amount of nutrients that accumulates in plant fruits or seeds depends mainly on the availability of each particular element in the soil and on the plant's ability to acquire and translocate these nutrients to the respective sink organs. Unfortunately, not much of the plant-derived food contains sufficient amounts of nutrients to meet the dietary requirements of humans. In particular cereal grains are inherently poor in iron $(\mathrm{Fe})$ and zinc $(\mathrm{Zn})$, although they are excellent sources of calories (White and Broadley, 2005; Cakmak, 2008; Newell-McGloughlin, 2008). Thus, a diet which is mainly based on cereals can lead to micronutrient malnutrition and contributes to the fact that almost half of the world's population suffers from diseases related to the deficiencies of $\mathrm{Fe}$ and/or Zn (WHO, 2002; Nestel et al., 2006). In this context, the improvement of $\mathrm{Fe}$ and $\mathrm{Zn}$ contents in cereal grains has become a high-priority research area (White and Broadley, 2005; Bouis et al., 2009). Recently, it has been demonstrated that strategies for micronutrient biofortification in plants are becoming economically efficient and suitable to combat micronutrient malnutrition in developing countries (Stein et al., 2007).

A substantial part of the nutrients accumulating in the vegetative tissue of a cereal plant is remobilized into the developing grains (Wiedemuth et al., 2005), a process that is induced during senescence in source tissues, in particular in leaves and stems (Gregersen et al., 2008). Relative to macronutrients like N, P, and $\mathrm{K}$, micronutrients are generally remobilized to a lower extent (Marschner, 2012). While only $20 \%$ of the ${ }^{59} \mathrm{Fe}$ applied to bean leaves was exported to sink leaves, this amount increased to $34 \%$ when senescence was induced by shading of ${ }^{59} \mathrm{Fe}$-supplied leaves (Zhang et al., 1995). In addition, it has recently been shown that $\mathrm{N}$ deficiency-or shading-induced leaf senescence enhances Fe mobilization in old leaves and favors $\mathrm{Fe}$ retranslocation from source to sink leaves in vegetatively growing barley plants (Shi et al., 2012). Moreover, the proportion of retranslocated nutrients is highly dependent on the micronutrient's mobility in the phloem. For instance, Fe has a comparatively moderate mobility in the phloem (Kochian, 1991), whereas $\mathrm{Zn}$ is highly phloem-mobile (Marschner, 2012) and up to $70 \%$ of the $\mathrm{Zn}$ from the vegetative parts of wheat plants can be retranslocated into the grains (Grusak et al., 1999).

During the retranslocation from source to sink tissues, Fe and $\mathrm{Zn}$ are transported through the phloem most likely in complexed forms. It is assumed that complex formation avoids precipitation of $\mathrm{Fe}$ and $\mathrm{Zn}$ as a consequence of the slightly alkaline $\mathrm{pH}$ and the relatively high $\mathrm{P}$ concentrations found in the phloem sap (Briat et al., 2007; Curie et al., 2009). In many plant species, nicotianamine (NA) appears to be the major chelator for $\mathrm{Fe}$ during retranslocation via the phloem, because (i) NA is able to form stable complexes with both $\mathrm{Fe}(\mathrm{II})$ and $\mathrm{Fe}(\mathrm{III})$ at neutral pHs (von Wirén et al., 1999); (ii) a decrease of NA levels 
in NA aminotransferase-expressing tobacco plants impaired Fe loading into seeds (Takahashi et al., 2003); and (iii) an increase in NA synthesis by activation tagging of a NA synthase (NAS) gene in rice led to higher $\mathrm{Zn}$ concentrations in transgenic rice (Lee et al., 2011). In graminaceous plant species, besides NA also phytosiderophores may play an important role during micronutrient transport in the phloem (Inoue et al., 2008). This is based on the observations that the phytosiderophore 2'-deoxymugineic acid (DMA) has been detected in the phloem sap of barley plants (Mori et al., 1991) and that Fe-DMA and Zn-NA complexes were found in the phloem sap of rice (Nishiyama et al., 2012). Since chelation plays such an important role during the long-distance transport of metal micronutrients, strategies for improving micronutrient contents in grains should also consider how they affect the pool of micronutrient chelators. With regard to a role in metal retranslocation, citrate has so far received little attention and only been considered as relevant for root-to-shoot translocation of Fe in the xylem (Rellan-Alvarez et al., 2010), although recent experiments indicated a substantial increase in Fe-citrate complexes in senescing barley leaves (Shi et al., 2012). This observation pointed to a likely involvement of citrate in the mobilization of $\mathrm{Fe}$ as a prerequisite for subsequent retranslocation.

One option to enhance micronutrients in grains is to supply crop plants with micronutrients in highly soluble forms by soil or foliar application. However, under most circumstances this strategy is costly and its effectiveness is often restricted to specific soil conditions and plant cultures (White and Broadley, 2009). Alternatively, the manipulation of nitrogen (N) nutrition can have a significant effect on the retranslocation of $\mathrm{Fe}$ and $\mathrm{Zn}$ in cereals. Nitrogen nutrition is assumed to have a positive effect, because $\mathrm{N}$ is required for the biosynthesis of NA and the Fe transport peptide ITP (Krüger et al., 2002; Shi et al., 2012). Additional supply of $\mathrm{N}$ has been shown to enhance the accumulation of $\mathrm{Fe}$ and $\mathrm{Zn}$ in wheat grains (Kutman et al., 2010, 2011; Shi et al., 2010; Aciksoz et al., 2011; Erenoglu et al., 2011). In part, this beneficial effect is related to the fact that the supply of sufficient amounts of $\mathrm{N}$ increases the grain protein concentrations, thereby increasing the sink strength of grains for Fe and $\mathrm{Zn}$. In line with this, previous reports have shown that protein concentrations correlate positively and significantly with $\mathrm{Fe}$ and $\mathrm{Zn}$ concentrations in grains (Peleg et al., 2008; Zhao et al., 2009). In addition, the N status can also affect the remobilization of micronutrients, since Fe export out of source leaves was inhibited under N-sufficient but stimulated under N-deficient growth conditions (Shi et al., 2012). Altogether these studies indicate that $\mathrm{N}$ management represents a promising agronomic strategy to improve micronutrient contents in wheat grains.

So far, most of the studies assessing the relation between $\mathrm{N}$ nutrition and micronutrient accumulation in grains were carried out in hydroponics or in the greenhouse (Aciksoz et al., 2011; Erenoglu et al., 2011; Kutman et al., 2011, 2012; Carlisle et al., 2012; Shi et al., 2012). To assess the practical relevance of $\mathrm{N}$ fertilization for improved grain metal concentrations, also field studies have been conducted which mostly support a positive effect of $\mathrm{N}$ on grain $\mathrm{Fe}$ or $\mathrm{Zn}$ accumulation in particular when root activity held on and Fe or Zn were supplied (Shi et al., 2010; Xue et al., 2012). However, most of the studies in wheat were conducted on sites conferring rather low or moderate grain yields (Shi et al., 2010; Xue et al., 2012), leaving it open whether also the important goal of $\mathrm{Fe}$ and $\mathrm{Zn}$ biofortification in cereals can also be attained under high-yielding conditions. Another aspect that has remained poorly investigated under field conditions is the impact of different inorganic $\mathrm{N}$ forms on micronutrient accumulation in grains. In most agricultural soils, nitrate $\left(\mathrm{NO}_{3}^{-}\right)$and ammonium $\left(\mathrm{NH}_{4}^{+}\right)$are the most abundant inorganic $\mathrm{N}$ forms. Besides serving as $\mathrm{N}$ source, these two $\mathrm{N}$ forms do also distinctly affect many physiological processes such as changes in rhizosphere $\mathrm{pH}$ or in the synthesis of organic acids which, in turn, may act as micronutrient chelators (Zou et al., 2001; Marschner, 2012). In a recent study, it has been reported that, compared to nitrate, the supply of ammonium to hydroponically-grown wheat plants resulted in a general increase in the concentrations of many nutrients, including $\mathrm{Fe}, \mathrm{Cu}$ as well as $\mathrm{Zn}$, and particularly bioavailable $\mathrm{Zn}$ (Carlisle et al., 2012). These results are likely related to the fact that nitrate and ammonium can cause distinct or even opposing effects on the $\mathrm{pH}$ of the rhizosphere and the apoplast of root or leaf cells as well as on the uptake, translocation and remobilization of micronutrients (Zou et al., 2001; Marschner, 2012). However, it is not yet fully understood whether nitrate or ammonium affects also other processes relevant for micronutrient accumulation in grains, such as flag leaf senescence or the synthesis and pool size of metal chelators.

Thus, the present study was designed to investigate the influence of a primarily nitrate- or ammonium-based $\mathrm{N}$ fertilization on the accumulation of micronutrients in the grains of fieldgrown winter wheat cultivated under high-yielding conditions. Particular attention was placed on the effect of these $\mathrm{N}$ forms at the onset of flag leaf senescence and its consequence for the availability of major metal ligands in flag leaves and leaf exudates.

\section{MATERIALS AND METHODS \\ PLANT MATERIAL AND GROWTH CONDITIONS}

Winter wheat (Triticum aestivum cv. Akteur) was grown on a gley tscherniza (Table 1) using common agriculture practices. Cation exchange capacity (CEC) was determined in $2 \mathrm{~mm}$-sieved soil, extracted by $1 \mathrm{M}$ ammonium chloride, $\mathrm{pH} 7.0$, and considering the sum of protons, $\mathrm{Ca}, \mathrm{Mg}, \mathrm{K}$, and $\mathrm{Na}$. Soil $\mathrm{N}$ was determined in dry-ashed soil samples following the Dumas principle. Micronutrients were determined by ICP-OES using $\mathrm{CaCl}_{2} / \mathrm{DTPA}$ extracts. Soil analysis was performed by a certified lab (Agrolab, Oberdorla, Germany). The field experiment was arranged in 30 $\mathrm{m}^{2}$ plots in a randomized block design, in which each treatment was represented once in four blocks, from which 10 plants were sampled in the middle of each plot for analyses. Before sowing, all plots received $40 \mathrm{~kg} \mathrm{~N} \mathrm{ha}^{-1}$ in the form of $\left(\mathrm{NH}_{4}\right)_{2} \mathrm{SO}_{4}$. At anthesis (EC65), fertilizer treatments consisted of no additional supply of $\mathrm{N}$ (control) or a broadcast application of $80 \mathrm{~kg}$ $\mathrm{N} \mathrm{ha}^{-1}$ in the form of either ammonium nitrate (nitrate-based treatment) or urea plus the nitrification inhibitor dicyandiamide (ammonium-based treatment). These fertilizer $\mathrm{N}$ forms were employed because undesired side effects of accompanying salts in the $\mathrm{N}$ fertilizer could be circumvented. $\mathrm{N}$ forms in the soil 
Table 1 | Selected soil characteristics and nutrient concentrations of the experimental field used in this study.

\begin{tabular}{|c|c|c|c|c|c|c|c|c|c|c|}
\hline Type of soil & CEC (mmol kg $\left.{ }^{-1}\right)$ & Organic matter (\%) & $\mathrm{pH}\left(\mathrm{CaCl}_{2}\right)$ & $\mathrm{N}(\%)$ & $\mathbf{P}$ & $\mathbf{K}$ & $\mathrm{Fe}$ & $\mathrm{Zn}$ & $M n$ & $\mathrm{Cu}$ \\
\hline
\end{tabular}

Soil samples were taken from a depth of 0 to $90 \mathrm{~cm}$. Micronutrient concentrations were measured in CaCl $2 / D T P A$ extracts.

solution were monitored in soil samples collected 5,10 , and 15 days after fertilizer application and sieving through a $2 \mathrm{~mm}$ mesh. Then, $10 \mathrm{~g}$ of the soil sample were extracted by $40 \mathrm{~mL}$ of a $25 \mathrm{mM}$ $\mathrm{CaCl}_{2}$ solution for $1 \mathrm{~h}$ and shaking at $220 \mathrm{rpm}$. After centrifugation $\left(20 \mathrm{~min}, 4500 \mathrm{rpm}, 4^{\circ} \mathrm{C}\right)$ the supernatant was analyzed for ammonium (Husted et al., 2000), nitrate, and urea (Kyllingsbaek, 1975) (Figure 1). To monitor changes in micronutrient contents in response to $\mathrm{N}$ fertilizer forms, flag leaves were harvested when they were still fully green (EC75) and, a second time, when they started to exhibit symptoms of senescence (EC85). Leaves from both developmental stages were used for chlorophyll, element and metabolite analysis or for the collection of leaf exudates. Spikes were harvested together with flag leaves at EC75 but for the second harvest at full maturity (EC99) to allow micronutrient re-allocation to be completed.

\section{CHLOROPHYLL DETERMINATION}

Total chlorophyll levels were assessed in flag leaves by following the protocol described in Lichtenthaler (1987). Briefly, $80 \%$ ethanol was added to $20 \mathrm{mg}$ homogenized leaf samples and incubated at $80^{\circ} \mathrm{C}$ for $60 \mathrm{~min}$. Samples were allowed to cool down for $15 \mathrm{~min}$ and centrifuged at room temperature. Double-distilled water was added to the supernatant and homogenized. Chlorophyll concentrations were measured by spectrophotometry (Guebel Instrumentelle Analytik, UVikon XL Biotek Instrument, Germany) at $652 \mathrm{~nm}$.

\section{COLLECTION OF LEAF EXUDATES}

In order to collect the exudates of flag leaves, single flag leaves were cut at their base and incubated immediately in a buffering solution containing $15 \mathrm{mM}$ EDTA at pH 7.5 as described in Weibull et al. (1990). Leaves were incubated in a growth cabinet (HPS 1500/S, Heraeus, Germany) for exudate collection over a period of $3 \mathrm{~h}$ at $21^{\circ} \mathrm{C}, 98 \%$ humidity and a light intensity of $120 \mu$ moles $\mathrm{m}^{-2} \mathrm{~s}^{-1}$.

\section{DETERMINATION OF NITROGEN AND MICRONUTRIENTS}

Nitrogen concentrations were determined in dried and ground samples of flag leaves or grains using an elemental analyzer (EA3000; Hekatech Germany). The concentrations of the micronutrients $\mathrm{Fe}, \mathrm{Zn}$, and $\mathrm{Cu}$ in flag leaves and in grains were measured by inductively-coupled plasma optic emission spectrometry (ICP-OES; iCAP, Thermo Scientific, Germany) after wet digestion of sample powder with nitric acid in a high-pressure digestion apparatus (UltraClave III, MLS, Leutkirch, Germany). For quality control, a certified reference material from the National Institute of Standards and Technology (Gaithersburg, USA) was used.
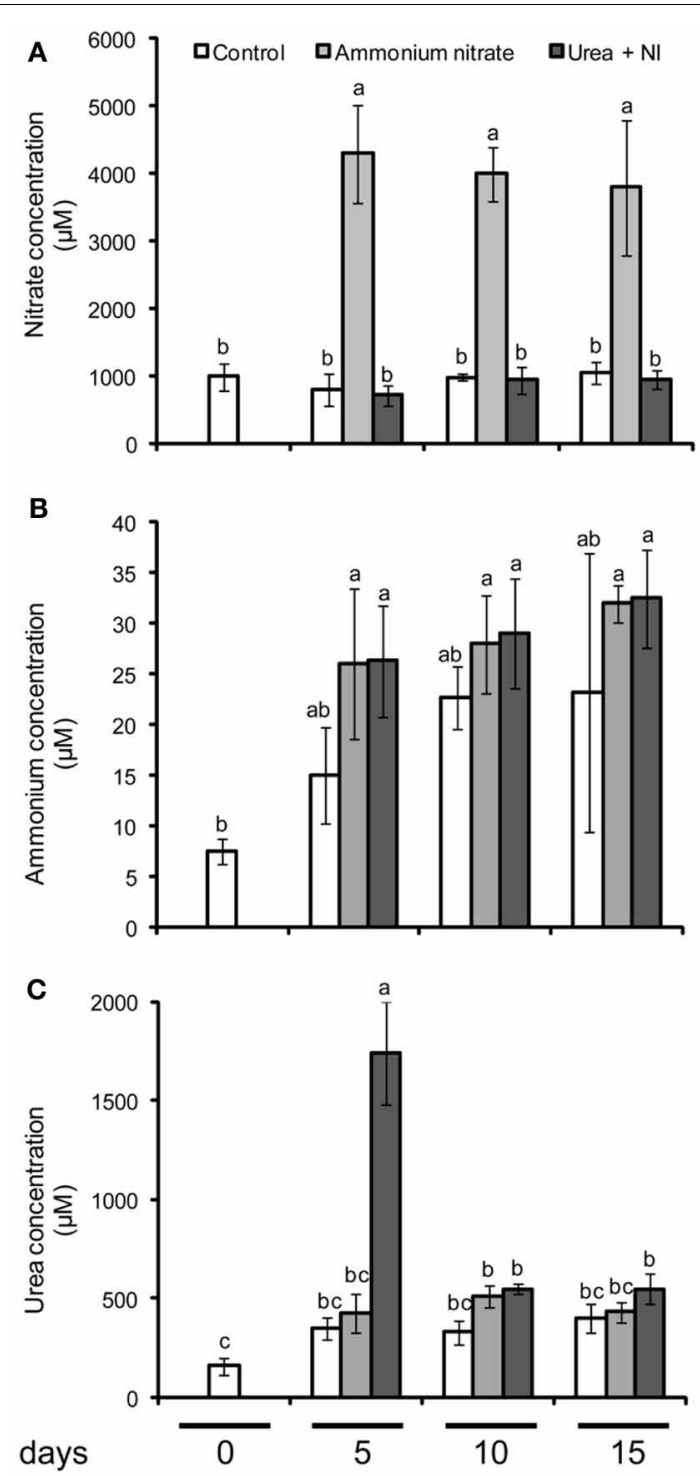

FIGURE 1 | Concentration of nitrate (A), ammonium (B), and urea (C) in soils after the fertilization of ammonium nitrate or urea + nitrification inhibitor (NI). Control soils did not receive any $\mathrm{N}$ fertilization. Shown are means $\pm \operatorname{SD}(n=4)$ Different letters indicate significant differences according to Tukey's test $(P \leq 0.05)$.

\section{SAMPLE FRACTIONATION AND CHELATOR ANALYSIS}

The levels of NA, DMA, and citrate in flag leaves and flag leaf exudates were determined exactly as described in Shi et al. (2012). Deep-frozen flag leaves were homogenized and 50-100 mg was 
used for extraction without derivatization. Extraction was made by adding $0.5 \mathrm{ml} 80 \%$ ethanol. Samples were then incubated at $80^{\circ} \mathrm{C}$ for $60 \mathrm{~min}$ and cooled down for about $15 \mathrm{~min}$. After centrifugation, the supernatant was removed and evaporated under vacuum at $55^{\circ} \mathrm{C}$. Samples were resuspended in $250 \mu \mathrm{l}$ ultrapure $\mathrm{H}_{2} \mathrm{O}$. The separation of organic acids was carried out using an AS11-HC column $(2 \times 250 \mathrm{~mm})$ connected to an AG11-HC $(2 \times$ $50 \mathrm{~mm}$ ) column and an ATC anion trap column. The gradient was accomplished with ultrapure water and increasing concentrations of $\mathrm{KOH}$ from a concentrated EluGen Catride EGC-KOH (Dionex, Idstein, Germany) and Eluent Generator EG40. The column was equilibrated at a flow rate of $0.25 \mathrm{ml}$ per minute with $4 \% \mathrm{KOH}$.

\section{AMINO ACID DETERMINATION}

For amino acid determinations, samples were prepared and concentrated under vacuum as described above. Then, $250 \mu \mathrm{l}$ of ultrapure $\mathrm{H}_{2} \mathrm{O}$ was used to resuspend the samples. The ACQ reagent (aminoquinolyl-N-hydroxysuccimidyl carbamate) was used for derivatization at $55^{\circ} \mathrm{C}$ for both leaves and leaf exudates (Cohen and Michaud, 1993). Amino acids were determined by HPLC mounted to an ALT2, Waters 2795 separation module and a multi fluorescence detector (model 2475, Waters $\mathrm{GmbH}$, Eschborn, Germany). The reagents reacted with primary and secondary amino acids to yield highly stable urea that fluoresce strongly at $400 \mathrm{~nm}$ after passing through a $\mathrm{xBridg}^{\mathrm{TM}} \mathrm{C} 18$ $3 \mu \mathrm{m}$ column. The buffer contained $140 \mathrm{mM}$ sodium acetate, adjusted by acetic acid (Suprapur Merck, Germany) to $\mathrm{pH}$ 5.8, and $7 \mathrm{mM}$ triethanolamine (Sigma, Germany), acetonitrile (Roti C Solv HPLC, Roth) and ultrapure $\mathrm{H}_{2} \mathrm{O}$. Data collection and calculations were carried out by the Empower software (Waters GmbH, Eschborn, Germany).

\section{DATA ANALYSIS}

Depending on the number of factors assessed, data were subjected to a One-Way or Two-Way ANOVA to assess the effect of treatments and their interactions on the analyzed traits (Table 2 and Table A1). Significant differences between means were then determined using the Tukey's test at 95\% confidence $(P \leq 0.05)$.

\section{RESULTS}

\section{INFLUENCE OF N FERTILIZATION ON N FORMS IN THE SOIL SOLUTION}

To verify whether the chosen $\mathrm{N}$ fertilizer forms were effective in providing a nitrate- or ammonium-based fertilization, we extracted soil samples 5, 10, and 15 days after fertilizer application for the analysis of nitrate, ammonium, and urea. Ammonium nitrate application enhanced nitrate concentrations in the soil solution to $>4 \mathrm{mM}$ over all sampling days, while they remained at $\sim 1 \mathrm{mM}$ in unfertilized soil or soil supplemented with urea + nitrification inhibitor (Figure 1A). In general, ammonium concentrations were up to two orders of magnitude lower than those of nitrate (Figure 1B), indicating that ammonium nitrate application clearly provided nitrate as the dominant $\mathrm{N}$ form. The application of urea + nitrification inhibitor was effective in enhancing ammonium concentrations in the soil solution from 15 to $20 \mu \mathrm{M}$ as in unfertilized soil samples to $25-30 \mu \mathrm{M}$, however, this level was also reached after ammonium nitrate application.
Table 2 | One-Way or Two-Way analysis of variance (ANOVA) of the effects of $\mathbf{N}$ fertilization, leaf developmental stage and their interactions on response variables of field-grown winter wheat (Triticum aestivum cv. Akteur).

\begin{tabular}{|c|c|c|c|}
\hline & $\begin{array}{l}\mathbf{N} \\
\text { fertilization }\end{array}$ & $\begin{array}{l}\text { Leaf dev. } \\
\text { stage }^{a}\end{array}$ & $\begin{array}{l}\mathrm{N} \text { fertil. } \times \text { leaf } \\
\text { dev. stage }\end{array}$ \\
\hline Dry weight of flag leaves & 0.358 & 0.058 & 0.283 \\
\hline Chlorophyll concentration & 0.015 & $<0.001$ & 0.974 \\
\hline $\mathrm{N}$ content of flag leaves & $<0.001$ & $<0.001$ & 0.473 \\
\hline Thousand grain weight ${ }^{b}$ & - & 0.385 & - \\
\hline Grain yield ${ }^{b}$ & - & 0.350 & - \\
\hline $\mathrm{N}$ content of grains & 0.001 & $<0.001$ & 0.004 \\
\hline Fe content of flag leaves & 0.487 & $<0.001$ & 0.143 \\
\hline Zn content of flag leaves & 0.505 & $<0.001$ & 0.633 \\
\hline $\mathrm{Cu}$ content of flag leaves & 0.089 & $<0.001$ & 0.483 \\
\hline Fe content of grains & $<0.001$ & $<0.001$ & $<0.001$ \\
\hline Zn content of grains & 0.038 & $<0.001$ & 0.019 \\
\hline $\mathrm{Cu}$ content of grains & 0.045 & $<0.001$ & $<0.001$ \\
\hline $\begin{array}{l}\text { NA concentration in flag } \\
\text { leaves }\end{array}$ & $<0.001$ & $<0.001$ & 0.003 \\
\hline $\begin{array}{l}\text { DMA concentration in } \\
\text { flag leaves }\end{array}$ & 0.521 & 0.209 & 0.697 \\
\hline $\begin{array}{l}\text { Citrate concentration in } \\
\text { flag leaves }\end{array}$ & 0.024 & $<0.001$ & $<0.001$ \\
\hline $\begin{array}{l}\text { NA exudation rate from } \\
\text { flag leaves }\end{array}$ & 0.206 & 0.002 & 0.017 \\
\hline $\begin{array}{l}\text { DMA exudation rate from } \\
\text { leaves }\end{array}$ & 0.090 & $<0.001$ & 0.001 \\
\hline $\begin{array}{l}\text { Total free amino acids in } \\
\text { flag leaves }\end{array}$ & 0.037 & $<0.001$ & 0.303 \\
\hline $\begin{array}{l}\text { Glutamine concentration } \\
\text { in flag leaves }\end{array}$ & 0.010 & $<0.001$ & $<0.001$ \\
\hline $\begin{array}{l}\text { Asparagine concentration } \\
\text { in flag leaves }\end{array}$ & $<0.001$ & $<0.001$ & $<0.001$ \\
\hline $\begin{array}{l}\text { Glutamate concentration } \\
\text { in flag leaves }\end{array}$ & 0.184 & $<0.001$ & 0.158 \\
\hline $\begin{array}{l}\text { Aspartate concentration } \\
\text { in flag leaves }\end{array}$ & 0.007 & $<0.001$ & 0.081 \\
\hline
\end{tabular}

The F-value probabilities at 95\% confidence are indicated.

${ }^{a}$ Refers to the developmental stage of either flag leaves (green or senescent) or grains (immature or mature).

${ }^{b}$ Assessed only at one harvest point (mature grains). Data was subjected to One-Way ANOVA.

By contrast, urea concentrations were elevated only 5 days after application of urea + nitrification inhibitor, providing proof for the limited stability of urea in the absence of an urease inhibitor (Figure 1C). These data suggested that the ammonium generated from the degradation of urea was rapidly and strongly adsorbed by the soil matrix. Such a high ammonium buffering capacity was not unexpected with regard to the high CEC of the soil (Table 1). As discussed below, the analysis of $\mathrm{N}$ and amino acids in the leaf samples were significantly increased after application of urea + nitrification inhibitor, in part even above the levels in ammonium nitrate-supplied plants, which is a typical response to ammonium-based fertilization (Figure 2C, Table 2). Thus, we 
concluded that the present methodological approach was valid to assign the ammonium nitrate application as a primarily nitratebased fertilization, while the application of urea + nitrification inhibitor reflected more an ammonium-based fertilization.

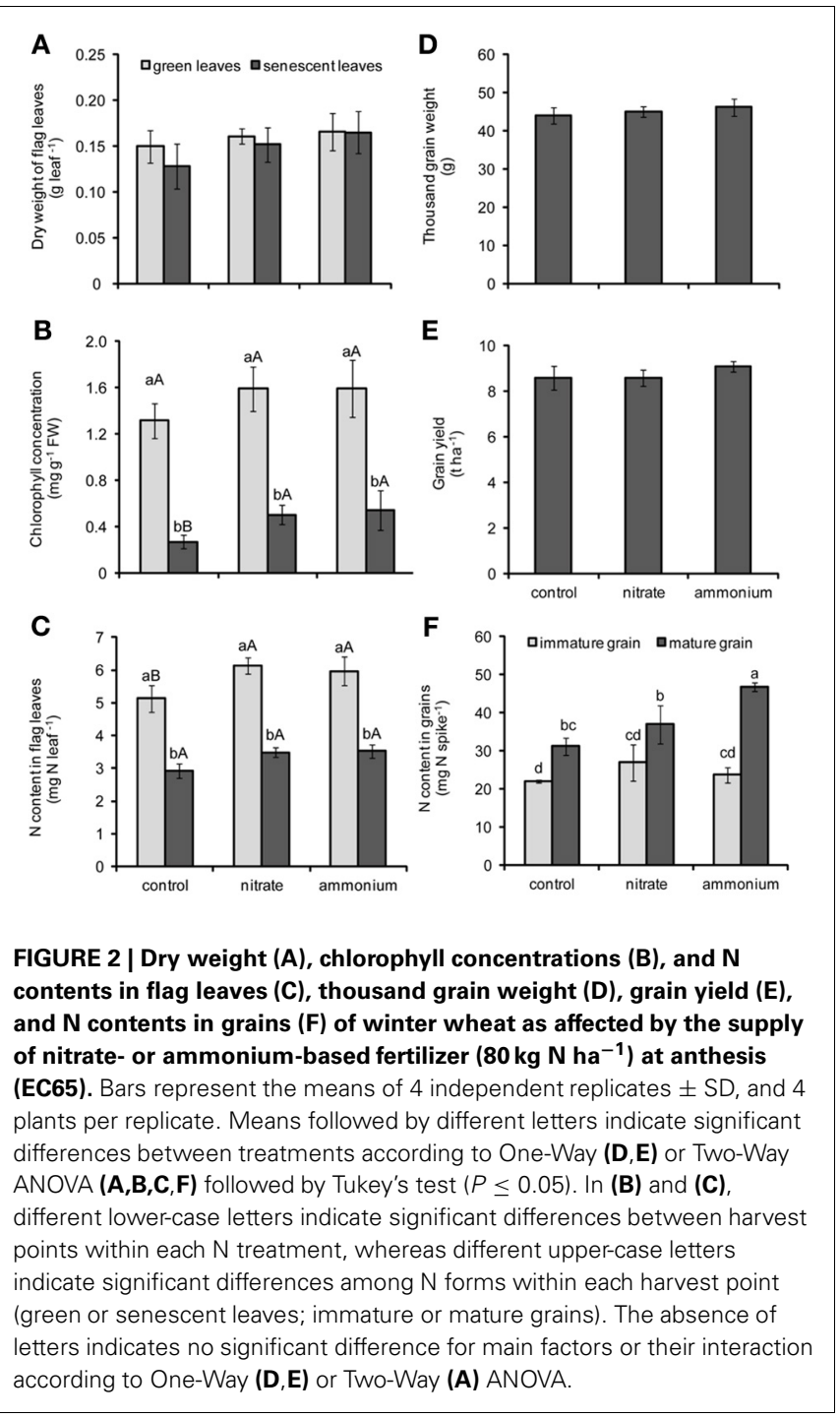

\section{INFLUENCE OF N FERTILIZATION ON NUTRIENT CONTENTS FLAG LEAVES}

In order to assess whether a supply with the two $\mathrm{N}$ formsammonium and nitrate-at EC65 had a distinctive effect on plant development or leaf senescence of wheat plants, flag leaves were harvested at two time points after broadcast application of the respective $\mathrm{N}$ fertilizers. According to the results of Two-Way ANOVA, chlorophyll concentrations were significantly affected by both $\mathrm{N}$ fertilization and leaf developmental stage (Table 2). In all treatments, leaves harvested at the later stage (EC85) were chlorotic and exhibited significantly lower chlorophyll concentrations than those from the earlier harvest (EC75; Figure 2B), reflecting the progression of leaf senescence. Importantly, this effect was not related to changes in the biomass of flag leaves, since this parameter was not altered by the leaf developmental stage or $\mathrm{N}$ treatments (Figure 2A). Irrespective of the fertilized $\mathrm{N}$ form, $\mathrm{N}$ supply maintained higher $\mathrm{N}$ contents in green leaves and higher chlorophyll concentrations in senescing leaves (Figures 2B,C). Thus, both $\mathrm{N}$ forms appeared to delay leaf senescence to a similar extent.

In addition to total $\mathrm{N}$, also the levels of amino acids were measured in flag leaves. As expected, the levels of all amino acids markedly decreased during flag leaf senescence (Table 3). The supply of both $\mathrm{N}$ forms increased the concentrations of glutamine and asparagine, whereas ammonium increased also the levels of aspartate in green leaves. However, the promoting effect of $\mathrm{N}$ fertilization on the amino acid pool declined at senescence. Even though the two $\mathrm{N}$ forms caused similar effects, ammonium-based fertilization led to a longer-lasting and more pronounced elevation of the amino acid pool which expressed particularly in a higher asparagine and aspartate accumulation in green leaves (Table 3). With regard to the higher amino acid accumulation usually seen under ammonium nutrition (Lang and Kaiser, 1994), this observation supported the view that the application of urea + nitrification inhibitor reflected a more ammonium-based $\mathrm{N}$ fertilization relative to the application of ammonium nitrate.

\section{INFLUENCE OF N FERTILIZATION ON YIELD TRAITS}

Both $\mathrm{N}$ treatments did neither significantly affect thousand grain weight nor grain yield (Figures 2D,E). Since several reports have indicated that the remobilization of micronutrients is associated with the remobilization of $\mathrm{N}$ (Kutman et al., 2010, 2011, 2012;

Table 3 | Effect of $\mathbf{N}$ forms on the concentration of amino acids in flag leaves of winter wheat (Triticum aestivum $\mathrm{L}$. cv. Akteur).

\begin{tabular}{|c|c|c|c|c|c|c|c|c|c|c|}
\hline \multirow[t]{2}{*}{ Treatments } & \multicolumn{2}{|c|}{$\begin{array}{l}\text { Total free amino acids } \\
\left(\mu \mathrm{mol} \mathrm{g}^{-1} \mathrm{FW}\right)\end{array}$} & \multicolumn{2}{|c|}{$\begin{array}{c}\text { Glutamine } \\
\left.\text { (nmol g } \mathbf{~}^{-1} \mathrm{FW}\right)\end{array}$} & \multicolumn{2}{|c|}{$\begin{array}{c}\text { Asparagine } \\
\left.\text { (nmol g } \mathbf{n}^{-1} \mathrm{FW}\right)\end{array}$} & \multicolumn{2}{|c|}{$\begin{array}{c}\text { Glutamate } \\
\text { (nmol g } \text { (n) }^{-1} \mathrm{FW}\end{array}$} & \multicolumn{2}{|c|}{$\begin{array}{c}\text { Aspartate } \\
\left(\mathrm{nmol} \mathrm{g} \mathbf{~}^{-1} \mathrm{FW}\right)\end{array}$} \\
\hline & Green & Senescent & Green & Senescent & Green & Senescent & Green & Senescent & Green & Senescent \\
\hline Control & $9.5 \mathrm{aB}$ & $2.6 \mathrm{bA}$ & 379 b & 193 b & 163 c & $29 c$ & 2132 a & 747 b & $940 \mathrm{aB}$ & 509 bA \\
\hline Nitrate & $15.2 \mathrm{aA}$ & $3.9 \mathrm{bA}$ & 1071 a & $273 b$ & $1450 \mathrm{~b}$ & $74 \mathrm{c}$ & 2660 a & 695 b & $1734 \mathrm{aB}$ & 545 bA \\
\hline Ammonium & $16.1 \mathrm{aA}$ & $5.0 \mathrm{bA}$ & 1035 a & $413 b$ & 2995 a & $45 c$ & 4114 a & $1113 b$ & $2100 \mathrm{aA}$ & 853 bA \\
\hline
\end{tabular}

Ammonium- or nitrate-based N fertilizers were supplied at anthesis (80 $\mathrm{kg} \mathrm{N} \mathrm{ha}^{-1}$ ). Leaves were harvested at EC75 (green) or EC85 (senescent). Values are means

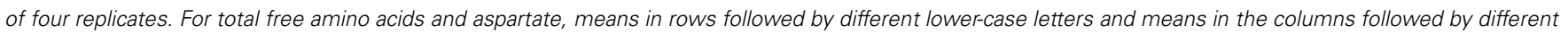

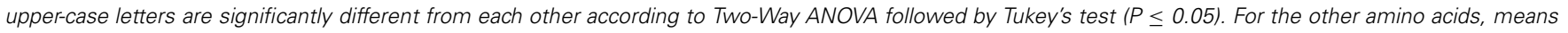
followed by different letters are significantly different from each other according to Two-Way ANOVA followed by Tukey's test (P $\leq 0.05)$. 
Shi et al., 2010; Erenoglu et al., 2011), N contents in grains were assessed and found to be significantly increased during grain maturity (Figure 2F). In addition, Two-Way ANOVA revealed a significant effect of the interaction between leaf developmental stage and $\mathrm{N}$ forms on $\mathrm{N}$ content in grains (Table 2). The application of $\mathrm{N}$ fertilizer tended to slightly increase the $\mathrm{N}$ contents of immature grains. In mature grains, however, ammonium-based fertilization increased grain $\mathrm{N}$ contents by $>50 \%$, while there was no significant increase after nitrate fertilization (Figure 2F). Notably, these higher $\mathrm{N}$ contents in ammonium-fertilized grains did not coincide with a more pronounced decrease in the $\mathrm{N}$ content of flag leaves (Figure 2C).

\section{INFLUENCE OF N FERTILIZATION ON MICRONUTRIENT ACCUMULATION IN FLAG LEAVES AND GRAINS}

According to the results of Two-Way ANOVA, the contents of $\mathrm{Fe}, \mathrm{Zn}$, and $\mathrm{Cu}$ in flag leaves were significantly affected only by the leaf developmental stage (Table 2). In fact, with progressing leaf senescence the contents of these micronutrients in flag leaves decreased significantly or at least in tendency as in case of Fe in nitrate-fertilized plants (Figures $\mathbf{3 A}, \mathbf{B}, \mathbf{C}$ ). In general, this decrease indicated that these micronutrients were remobilized and exported out of the flag leaves during senescence. The supply of either $\mathrm{N}$ fertilizer to the plants did not significantly nor distinctively affect this process. The concentration of $\mathrm{Fe}, \mathrm{Zn}$ and $\mathrm{Cu}$ were
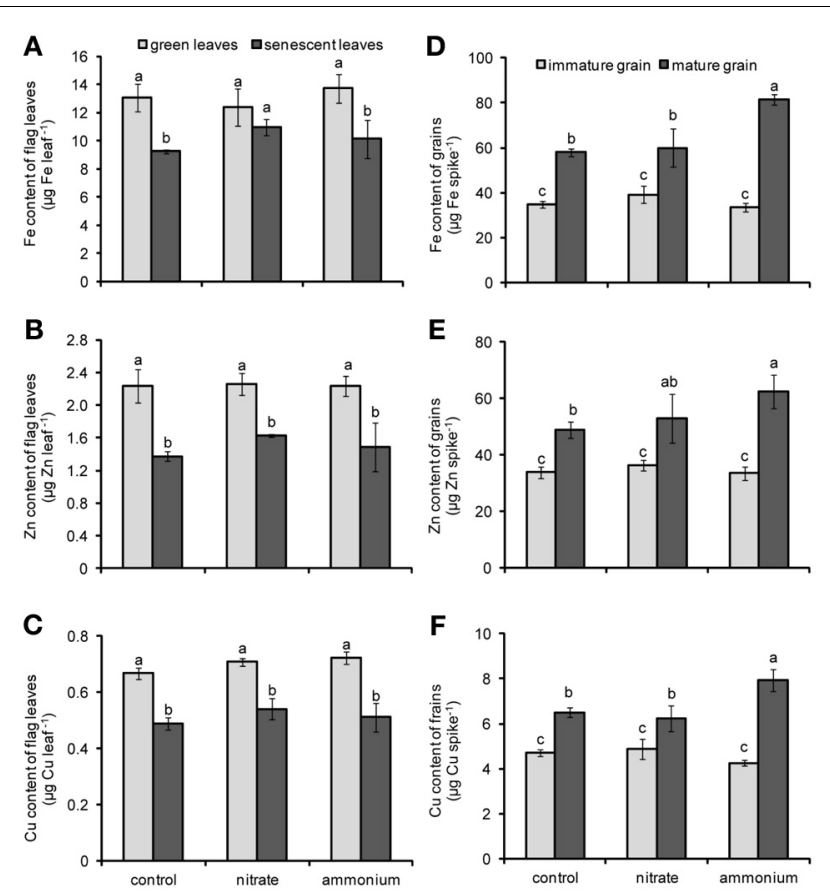

FIGURE 3 | Contents of Fe (A,D) Zn (B,E), and $\mathrm{Cu}(C, F)$ in flag leaves $(A, B, C)$ or grains $(D, E, F)$ of winter wheat as affected by nitrate- or ammonium-based fertilization ( $80 \mathrm{~kg} \mathrm{~N} \mathrm{ha}^{-1}$ ) at anthesis (EC65). Bars represent the means of 4 independent replicates $\pm S D$, and 4 plants per replicate. Means followed by different letters indicate significant differences between treatments according to Two-Way ANOVA followed by Tukey's test $(P \leq 0.05)$. only slightly affected by the leaf developmental stage or the $\mathrm{N}$ fertilization (Figure A2). Regarding the contents of micronutrients in grains, Two-Way ANOVA revealed that not only the $\mathrm{N}$ fertilization and the leaf developmental stage, but also their interactions had significant effects on these traits (Table 2). The contents of $\mathrm{Fe}, \mathrm{Zn}$, and $\mathrm{Cu}$ increased as grains matured (Figures 3D,E,F). Importantly, the supply of a primarily ammonium-based fertilizer stimulated this increase only in mature but not in immature grains. Compared to non-fertilized and nitrate-supplied plants, the ammonium-based fertilization increased Fe contents in grains by almost $40 \%$ (Figure 3D) and those of $\mathrm{Zn}$ and $\mathrm{Cu}$ by 27 and $22 \%$, respectively (Figures 3E,F). Thus, the increase in grain micronutrient contents after ammonium-based fertilization of wheat plants went along with a higher $\mathrm{N}$ content in the grains (Figure 2F) but not with a concomitant stimulation of micronutrient losses in flag leaves (Figures 3A-C).

\section{INFLUENCE OF N FERTILIZATION ON NA, DMA, AND CITRATE LEVELS}

The determination of micronutrient contents in flag leaves indicated that $\mathrm{Fe}, \mathrm{Zn}$, and $\mathrm{Cu}$ were remobilized from flag leaves during senescence (Figure 3). Since $\mathrm{Fe}, \mathrm{Zn}$, and $\mathrm{Cu}$ are assumed to be retranslocated via the phloem in complexed forms (Briat et al., 2007; Curie et al., 2009), changes in the concentrations of three major micronutrient ligands, namely NA, DMA, and citrate, were assessed in flag leaves. Whereas treatments had no significant effect on DMA levels, the main effects of $\mathrm{N}$ fertilization, leaf developmental stage and the effect of their interactions were significant for NA and citrate concentrations in leaves (Table 2). In case of NA, the supply of either $\mathrm{N}$ form strongly increased the concentration of NA in green flag leaves (Figure 4A) suggesting that the synthesis of this $\mathrm{N}$-containing chelator was highly stimulated by $\mathrm{N}$ supply. In senescent flag leaves, NA concentrations were dramatically depleted in all treatments, even though NA levels remained slightly higher in ammonium-supplied plants (Figure 4A). In contrast, the levels of DMA only tended to be somewhat higher in senescing $\mathrm{N}$-supplied leaves (Figure 4B). A striking difference to NA, however, was observed in the progression of DMA concentrations during senescence, when DMA levels did not decrease but stayed high. Similar to NA, also citrate levels decreased markedly during leaf senescence (Figure 4C) and $\mathrm{N}$ supply promoted citrate levels only in green but not any more in senescent leaves. However, there was no differential effect of the $\mathrm{N}$ form on citrate concentrations in flag leaves.

To gain an insight on the effects of $\mathrm{N}$ forms and leaf senescence on the retranslocation of micronutrient chelators, the levels of NA and DMA were also determined in exudates collected from flag leaves. Unfortunately, the amount of exudates collected was too small to determine citrate levels. The effect of the interaction between $\mathrm{N}$ fertilization and leaf developmental stage on NA and DMA exudation rates was significant (Table 2). In case of NA, $\mathrm{N}$ supply tended to decrease exudation rates from green leaves, whereas $\mathrm{N}$ supply increased the exudation of NA from senescent leaves (Figure 5A). Noteworthy, NA exudation rates from flag leaves of $\mathrm{N}$-treated plants showed an opposite pattern as compared to the concentrations of NA detected in flag leaves (Figures 5A, 4A), further supporting that NA was exported out 

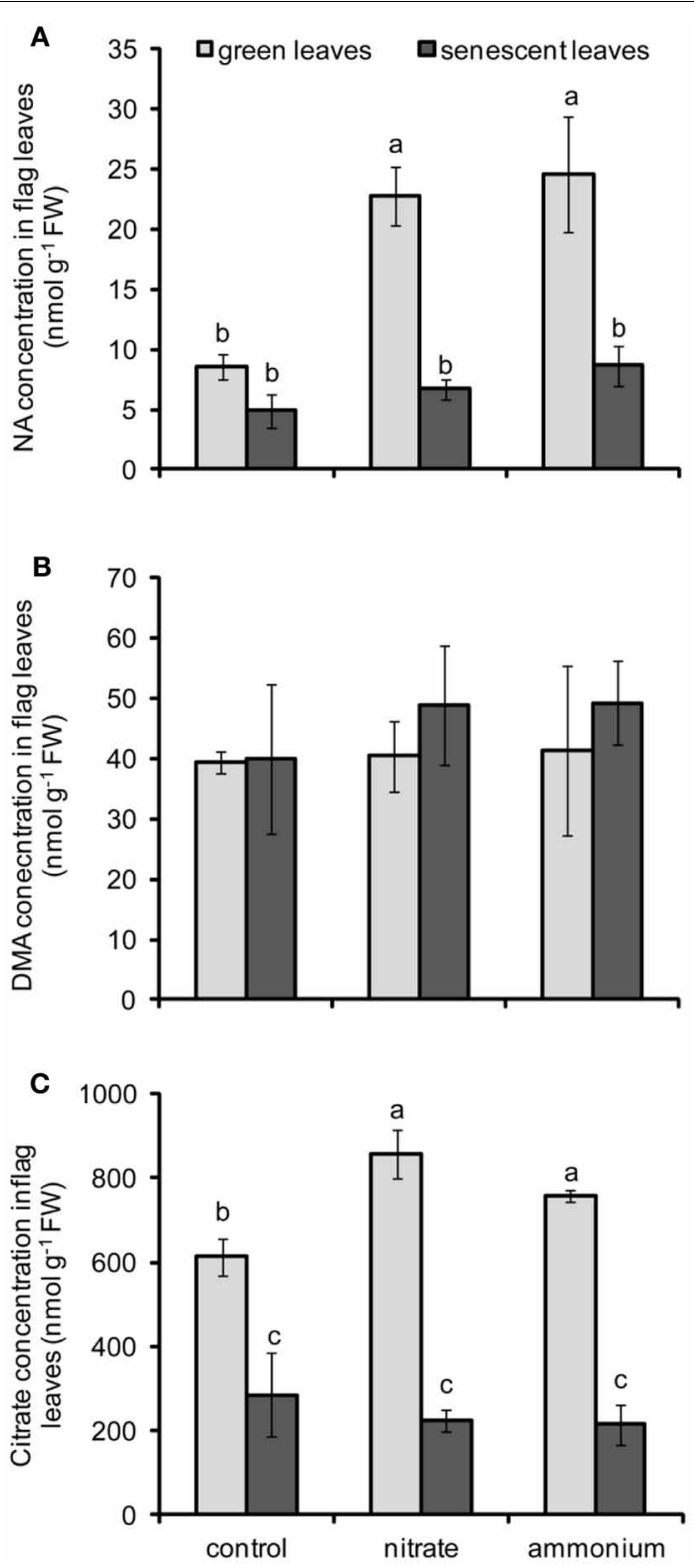

FIGURE 4 | Concentrations of NA (A), DMA (B), and citrate (C) in flag leaves of winter wheat as affected by nitrate- or ammonium-based fertilization ( $80 \mathbf{~ k g ~ N ~ h a}^{-1}$ ) at anthesis (EC65). Bars represent the means of 4 independent replicates $\pm S D$, and 4 plants per replicate. Means followed by different letters indicate significant differences between treatments according to Two-Way ANOVA followed by Tukey's test $(P \leq 0.05)$. The absence of letters $(\mathbf{B})$ indicates no significant difference for the main factors or their interaction according to Two-Way ANOVA.

of these leaves during senescence. In contrast, $\mathrm{N}$ supply did not considerably affect the exudation of DMA from green flag leaves, but significantly reduced DMA export from senescent leaves of plants treated with either $\mathrm{N}$ form (Figure 5B). These results indicated that $\mathrm{N}$ supply stimulated the export of NA but not of DMA out of senescing flag leaves. Nevertheless, DMA export rates from flag leaves remained at least hundred-fold higher than those of NA at any developmental stage.
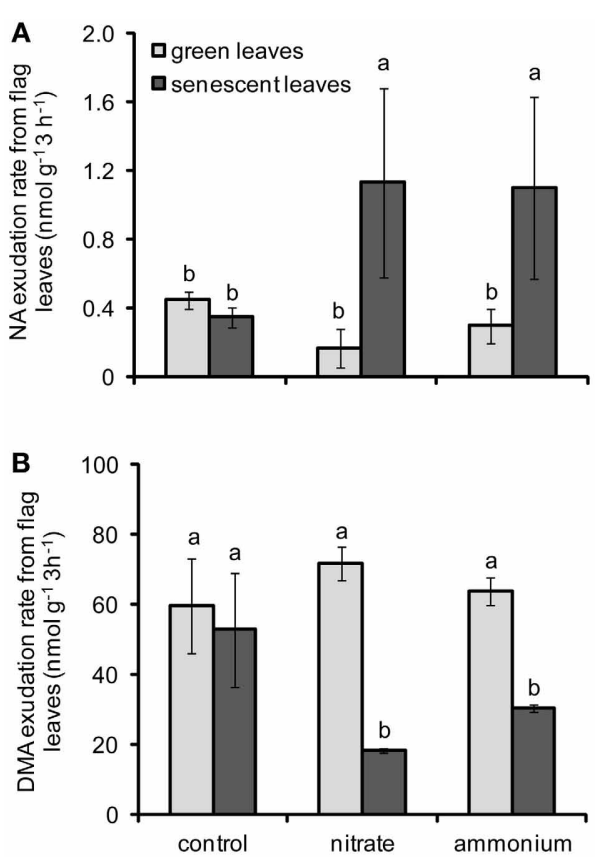

FIGURE 5 | Exudation rates of NA (A) and DMA (B) from flag leaves of winter wheat as affected by nitrate- or ammonium-based fertilization (80 $\mathbf{~ k g ~ N ~ h a - 1 )}$ ) at anthesis (EC65). Bars represent the means of 4 independent replicates $\pm S D$, and 4 plants per replicate. Means followed by different letters indicate significant differences between treatments according to Two-Way ANOVA followed by Tukey's test $(P \leq 0.05)$.

\section{DISCUSSION}

Earlier studies have indicated that an increasing N nutritional status of cereal plants can significantly improve Fe and Zn loading into grains. Thereby, high $\mathrm{N}$ supplies to wheat plants enhanced not only the acquisition and translocation of $\mathrm{Fe}$ and $\mathrm{Zn}$ to grains but also appeared to stimulate $\mathrm{Zn}$ retranslocation out of flag leaves and other plant organs (Kutman et al., 2010, 2011, 2012; Shi et al., 2010; Erenoglu et al., 2011). These studies indicated that $\mathrm{N}$ management is a promising route to improve micronutrient contents in cereal grains. The extent of remobilization, however, also depends on the nutritional status of the respective micronutrient. For instance, when plants were well-supplied with $\mathrm{Fe}, \mathrm{N}$ supply decreased Fe retranslocation out of source leaves, probably because fertilized $\mathrm{N}$ created an additional sink for this metal in source leaves (Shi et al., 2012). Similarly, the amount of retranslocated $\mathrm{Zn}$ increased with $\mathrm{N}$ supply to a larger extent in $\mathrm{Zn}$-deficient relative to Zn-sufficient wheat plants (Erenoglu et al., 2011). Thus, in order to obtain maximum gain in terms of micronutrient enrichment in grains, $\mathrm{N}$ fertilization has to be managed in a rational manner. Against this background, our study placed special emphasis on the influence of $\mathrm{N}$ fertilization and $\mathrm{N}$ fertilizer forms on metal and chelator pools in senescing source tissues, employing flag leaves as a relevant model organ for metal remobilization processes.

As flag leaves started to senesce, it was observed that the contents of Fe, Zn, and Cu decreased significantly (Figures 3A,B,C), whereas they progressed to increase in developing grains 
(Figures 3D,E,F). In average, up to 20, 32, and 27\% of flag leaf $\mathrm{Fe}, \mathrm{Zn}$, and $\mathrm{Cu}$, respectively, were exported during leaf senescence (between stage EC75 and EC85). Previously, it has been reported that in sand-grown wheat up to $77 \%$ of shoot Fe was retranslocated to grains (Garnett and Graham, 2005). In contrast, in field-grown wheat Fe retranslocation during seed filling was negligible and not comparable to the values measured for Zn (Hocking, 1994). Such variable extents of metal retranslocation may relate to the nutritional status of the plants with the respective nutrients. In our case, soil $\mathrm{pH}$ was slightly alkaline and DTPA-extractable metal concentrations in the soil generally indicated low availabilities for $\mathrm{Fe}, \mathrm{Zn}$ and $\mathrm{Cu}$ (Table 1). As a consequence $\mathrm{Fe}$ and $\mathrm{Cu}$ concentrations in green leaves were close to or, as in case of $\mathrm{Zn}$, even slightly below the critical levels reported for wheat (Figure A1; Bergmann, 1992; Marschner, 2012). These data indicated that the nutritional status was favorable to promote metal retranslocation and supported the expectation that a beneficial and eventually differential effect of $\mathrm{N}$ fertilizer forms on metal retranslocation may be seen.

With regard to the possibility that different $\mathrm{N}$ forms may alter flag leaf metabolism or development and thereby micronutrient retranslocation, the most striking observation was that a primarily ammonium-based $\mathrm{N}$ fertilization after anthesis increased the accumulation of $\mathrm{Fe}, \mathrm{Zn}$, and $\mathrm{Cu}$ in grains (Figures 3D,E,F). The effect of ammonium on micronutrient accumulation was not related to a change in the progression of senescence, since ammonium-treated plants did not differ from nitrate-supplied plants with respect to chlorophyll or total $\mathrm{N}$ concentrations in the flag leaf at either the earlier or later harvest (Figures 2B,C). Nevertheless, slightly higher chlorophyll and leaf $\mathrm{N}$ concentrations after preferential nitrate- or ammonium-based fertilizer indicated that $\mathrm{N}$ fertilization was effective. Most of the $\mathrm{N}$ that ends up in wheat grains originates from the retranslocation of amino acids out of the vegetative organs, especially from flag leaves (Gregersen et al., 2008; Masclaux-Daubresse et al., 2008). A significant proportion of $\mathrm{N}$ can also be taken up from the soil after anthesis, if root activity has not yet ceased (Kichey et al., 2007). With regard to the low molecular-weight $\mathrm{N}$ pool that is usually dominated by amino acids, the supply of either inorganic $\mathrm{N}$ form significantly increased the concentrations of glutamine and asparagine in green flag leaves (Table 3). Since the extent of the depletion of $\mathrm{Fe}, \mathrm{Zn}$, and $\mathrm{Cu}$ in flag leaves of primarily ammonium- and nitrate-supplied plants was similar (Figures 3A,B,C), we consider it unlikely that the increased asparagine or slightly increased total amino acid levels in flag leaves and leaf exudates of ammonium-supplied plants were causally related to their elevated micronutrient contents in the grains. In another case, it has been shown that ammonium can promote $\mathrm{Fe}$ retranslocation from old to young leaves in maize (Zou et al., 2001), although this effect was more obvious when plants were grown under low Fe. Considering the growing evidence that $\mathrm{Fe}$ and $\mathrm{Zn}$ retranslocation out of flag leaves is tightly related to the retranslocation of $\mathrm{N}$ (Uauy et al., 2006; Shi et al., 2012), metal losses in senescent flag leaves were monitored. However, $\mathrm{Fe}, \mathrm{Zn}$, or $\mathrm{Cu}$ contents in flag leaves were not more decreased under preferential ammonium vs. nitrate nutrition (Figures 3A,B,C). Hence, the higher accumulation of these metal micronutrients in grains of ammonium-supplied plants (Figures 3D,E,F) was not caused by altered retranslocation processes. Moreover, control and nitrate-supplied plants accumulated similar amounts of these metals in the grain, suggesting that the total amount of added $\mathrm{N}$ fertilizer was not as relevant for metal accumulation in grains as the $\mathrm{N}$ fertilizer form. We therefore conclude that post-anthesis ammonium fertilization rather stimulated the de novo acquisition of micronutrient metals. A reason for this may be found in the rhizosphere acidification of ammonium-fertilized plants (Sarkar and Jones, 1982) or a longer lasting availability of ammonium-N, considering the high CEC of the soil used in this study (Table $\mathbf{1}$ ).

The root-to-shoot translocation in the xylem as well as the re-translocation of $\mathrm{Fe}$ and $\mathrm{Zn}$ in the phloem are facilitated by endogenous chelators such as NA and DMA, which are synthesized from methionine and are thus dependent on the $\mathrm{N}$ nutritional status. In agreement with this, we observed that a late application of $\mathrm{N}$ fertilizers to wheat plants significantly increased NA concentrations in flag leaves as well as NA exudation rates from senescing flag leaves (Figures 4A, 5A). In particular the latter suggested that in N-supplied plants more NA can be loaded into the phloem for long-distance transport. By contrast, DMA concentrations in the flag leaves were barely affected by $\mathrm{N}$, and DMA export was even slightly repressed after $\mathrm{N}$ supply (Figures 4B, 5B). In rice plants, both of these chelators were found in the phloem sap: NA mainly as a Zn-NA complex and DMA predominantly complexed to Fe(III) (Nishiyama et al., 2012). Together with studies on transgenic, NAS-overexpressing plants (Lee et al., 2011), these reports emphasize the importance of NA and DMA for metal re-translocation. Unlike most other studies, our approach of collecting leaf exudates as an approximation for phloem sap additionally allowed comparing metal chelator availabilities and export from leaves at a quantitative level. In agreement with our previous observations in flag leaves of hydroponically-grown barley (Shi et al., 2012), we found much higher concentrations of DMA than of NA, not only in flag leaves but also in leaf exudates of field-grown wheat. Although this implies a far higher metal chelation potential by DMA, this may apply to $\mathrm{Fe}, \mathrm{Zn}$, and $\mathrm{Cu}$ in different ways with respect to their different complex stabilities (von Wirén et al., 1999). Moreover, the corresponding metal complexes are most likely also subject to differential phloem loading, since at least some of the YS1- and YSL-related transporters involved in long-distance metal-chelate transport may show differential preferences (Schaaf et al., 2004; Zheng et al., 2012). With regard to NA or DMA concentrations in leaves and in leaf exudates, none of the chelator pools investigated here responded differently to ammonium- or nitrate-based fertilization (Figures 4, 5). It is thus concluded that the $\mathrm{N}$ fertilizer form applied at anthesis had no particular impact on the mobilization and phloem loading of $\mathrm{Fe}, \mathrm{Zn}$, and $\mathrm{Cu}$ as well as their associated chelators in senescing flag leaves.

\section{CONCLUSIONS}

Taken together, the present study found no evidence for $\mathrm{N}$ fertilization at anthesis increasing the export of $\mathrm{Fe}, \mathrm{Zn}$, and $\mathrm{Cu}$ from senescing flag leaves of wheat plants, although in particular NA pools responded positively to additional N supply. 
Similar to metal export, DMA concentrations were poorly affected by $\mathrm{N}$ fertilization. Nevertheless, DMA may be more relevant than NA for the mobilization and retranslocation of these metals in wheat, because far higher concentrations of DMA relative to NA were found in leaves and leaf exudates. Although the even higher concentrations of citrate may also contribute to metal retranslocation, it must be considered that metal-complex stabilities with citrate are several orders of magnitude lower than those of NA or DMA. While fertilized N forms did not affect metal retranslocation, the post-anthesis supply of ammoniumbased fertilizer resulted in an elevated accumulation of these micronutrients in grains which was associated with a higher accumulation of $\mathrm{N}$. This suggests that ammonium-based $\mathrm{N}$ fertilization was more effective than nitrate in stimulating the acquisition and translocation of micronutrient metals. To what extent

\section{REFERENCES}

Aciksoz, S. B., Yazici, A., Ozturk, L., Cakmak, I. (2011). Biofortification of wheat with iron through soil and foliar application of nitrogen and iron fertilizers. Plant Soil 349, 215-225. doi: 10.1007/s11104-0110863-2

Bergmann, W. (1992). Nutritional Disorders in Plants: Development, Visual and Analytical Diagnosis. Jena: Gustav Fisher.

Bouis, H. E., Hotz, C., McClafferty, B., Meenakshi, J. V., Pfeiffer, W. H., Eozenou, P., et al. (2009). Biofortification: a new tool to reduce micronutrient malnutrition. Ann. Nutr. Metab. 55, 57-58.

Briat, J. F., Curie, C., and Gaymard, F. (2007). Iron utilization and metabolism in plants. Curr. Opin. Plant Biol. 10, 276-282. doi: 10.1016/j.pbi.2007.04.003

Cakmak, I. (2008). Enrichment of cereal grains with zinc: agronomic or genetic biofortification? Plant Soil 302, 1-17. doi: 10.1007/s11104007-9466-3

Carlisle, E., Myers, S., Raboy, V., and Bloom, A. (2012). The effects of inorganic nitrogen form and $\mathrm{CO}_{2}$ concentrations on wheat yield and nutrient accumulation and distribution. Front. Plant Sci. 3:195. doi: 10.3389/fpls.2012.00195

Cohen, S. A., and Michaud, D. P. (1993). Synthesis of a fluorescent derivatizing reagent, 6-aminoquinolyl-Nhydroxysuccinimidyl carbamate, and its application for the analysis of hydrolysate amino-acids via high-performance liquidchromatography. Anal. Biochem. 211, 279-287. doi: 10.1006/abio. 1993.1270

Curie, C., Cassin, G., Couch, D., Divol, F., Higuchi, K., Jean, M., et al. (2009). Metal movement within the plant: contribution of nicotianamine and yellow stripe 1-like transporters. Ann. Bot. 103, 1-11. doi: $10.1093 / \mathrm{aob} / \mathrm{mcn} 207$

Erenoglu, E. B., Kutman, U. B., Ceylan, Y., Yildiz, B., and Cakmak, I. (2011). Improved nitrogen nutrition enhances root uptake, root-to-shoot translocation and remobilization of zinc $\left({ }^{65} \mathrm{Zn}\right)$ in wheat. New Phytol. 189, 438-448. doi: 10.1111/j.1469-8137.2010.03488.x

Garnett, T. P., and Graham, R. D. (2005). Distribution and remobilization of iron and copper in wheat. Ann. Bot. 95, 817-826. doi: 10.1093/aob/mci085

Gregersen, P. L., Holm, P. B., and Krupinska, K. (2008). Leaf senescence and nutrient remobilisation in barley and wheat. Plant Biol. 10, 37-49. doi: 10.1111/j.1438-8677.2008.00114.x

Grusak, M. A., Pearson, J. N., and Marentes, E. (1999). The physiology of micronutrient homeostasis in field crops. Field Crop Res. 60, 41-56. doi: 10.1016/S0378-4290(98)00132-4

Hocking, P. J. (1994). Dry-matter production, mineral nutrient concentrations, and nutrient distribution and redistribution in irrigated spring wheat. J. Plant Nutr. 17, 1289-1308. doi: 10.1080/01904169409364807

Husted, S., Hebbern, C. A., Mattsson, M., and Schjoerring, J. K. (2000). A critical experimental evaluation of methods for determination of NH4+ in plant tissue, xylem sap and apoplastic fluid. Physiol. Plant. 109, 167-179. doi: 10.1034/j.13993054.2000.100209.x

Inoue, H., Takahashi, M., Kobayashi, T., Suzuki, M., Nakanishi, H., Mori, S., et al. (2008). Identification and localisation of the rice nicotianamine aminotransferase

$\mathrm{N}$-dependent metal chelators contributed to these processes, requires further investigations.

\section{ACKNOWLEDGMENTS}

This work was supported with a fellowship to Nunun Barunawati from the Ministry of Education and Culture (DIKTI), Republic of Indonesia and by the Bundesministerium für Bildung und Forschung, Germany, in the frame of an European Transnational Cooperation (Germany, France, Spain) within the PLANT-KBBE Initiative "HotIron" (FKZ:0315458B to Nicolaus von Wirén). We thank Dr. Rongli Shi, IPK Gatersleben, for critically reading the manuscript, Dr. M. Hajirezaei and Reza Ghaffari for support with the HPLC analysis and Peter Schreiber, Dagmar Böhmert, and Christa Kallas for help with the field studies.

gene OsNAAT1 expression suggests the site of phytosiderophore synthesis in rice. Plant Mol. Biol. 66, 193-203. doi: 10.1007/s11103-0079262-8

Kichey, T., Hirel, B., Heumez, E., Dubois, F., and Le Gouis, J. (2007). In winter wheat (Triticum aestivum L.), post-anthesis nitrogen uptake and remobilisation to the grain correlates with agronomic traits and nitrogen physiological markers. Field Crop Res. 102, 22-32. doi: 10.1016/j.fcr.2007.01.002

Kochian, L. V. (1991). "Mechanisms of micronutrient uptake and translocation in plants," in Micronutrients in Agriculture, eds F. R. Cox, J. J. Mortvedt, L. M. Shuman, and R. M. Welch (Madison, WI: Soil Science Society of America), 229-296.

Krüger, C., Berkowitz, O., Stephan, U. W., and Hell, R. (2002). A metal-binding member of the late embryogenesis abundant protein family transports iron in the phloem of Ricinus communis L. J. Biol. Chem. 277, 25062-25069. doi: 10.1074/jbc.M201896200

Kutman, U. B., Kutman, B. Y., Ceylan, Y., and Cakmak, I. (2012). Contributions of root uptake and remobilization to grain zinc accumulation in wheat depending on post-anthesis zinc availability and nitrogen nutrition. Plant Soil 361, 177-187. doi: 10.1007/s11104012-1300-x

Kutman, U. B., Yildiz, B., and Cakmak, I. (2011). Effect of nitrogen on uptake, remobilization and partitioning of zinc and iron throughout the development of durum wheat. Plant Soil 342, 149-164. doi: 10.1007/s11104-010-0679-5

Kutman, U. B., Yildiz, B., Ozturk, L., and Cakmak, I. (2010). Biofortification of durum wheat with zinc through soil and foliar applications of nitrogen. Cereal Chem. 87, 1-9. doi: 10.1094/CCHEM-87-1-0001

Kyllingsbaek, A. (1975). Extraction and colorimetric determination of urea in plants. Acta Agric. Scand. 25, 109-112. doi: $10.1080 / 00015127509436239$

Lang, B., and Kaiser, W. M. (1994). Solute content and energy status of roots of barley plants cultivated at different $\mathrm{pH}$ on nitrate-nitrogen or ammonium-nitrogen. New Phytol. 128, 451-459. doi: 10.1111/j.14698137.1994.tb02991.x

Lee, S., Persson, D. P., Hansen, T. H., Husted, S., Schjoerring, J. K., Kim, Y. S., et al. (2011). Bioavailable zinc in rice seeds is increased by activation tagging of nicotianamine synthase. Plant Biotechnol. J. 9, 865-873. doi: 10.1111/j.1467-7652.2011.00606.x

Lichtenthaler, H. K. (1987). Chlorophylls and carotenoids pigments of photosynthetic biomembranes. Methods Enzymol. 148, 350-382. doi: 10.1016/00766879(87)48036-1

Marschner, P. (2012). Marschner's Mineral Nutrition of Higher Plants. San Diego, CA: Academic Press.

Masclaux-Daubresse, C., ReisdorfCren, M., and Orsel, M. (2008). Leaf nitrogen remobilisation for plant development and grain filling. Plant Biol. 10, 23-36. doi: 10.1111/j.1438-8677.2008.00097.x

Mori, S., Nishizawa, N., Hayashi, H., Chino, M., Yoshimura, E., and Ishihara, J. (1991). Why are young rice plants highly susceptible to iron deficiency. Plant Soil 130, 143-156. doi: 10.1007/BF00011869

Nestel, P., Bouis, H. E., Meenakshi, J. V., and Pfeiffer, W. (2006). Biofortification of staple food crops. J. Nutr. 136, 1064-1067. 
Newell-McGloughlin, M. (2008). Nutritionally improved agricultural crops. Plant Physiol. 147, 939-953. doi: 10.1104/pp.108.121947

Nishiyama, R., Kato, M., Nagata, S., Yanagisawa, S., and Yoneyama, T. (2012). Identification of Zn-nicotianamine and $\mathrm{Fe}-2$ 'deoxymugineic acid in the phloem sap from rice plants (Oryza sativa L.). Plant Cell Physiol. 53, 381-390. doi: $10.1093 /$ pcp/pcr188

Peleg, Z., Saranga, Y., Yazici, A., Fahima, T., Ozturk, L., and Cakmak, I. (2008). Grain zinc, iron and protein concentrations and zinc-efficiency in wild emmer wheat under contrasting irrigation regimes. Plant Soil 306, 57-67. doi: 10.1007/s11104-007-9417-z

Rellan-Alvarez, R., Giner-MartinezSierra, J., Orduna, J., Orera, I., Rodriguez-Castrillon, J. A., Garcia-Alonso, J. I., et al. (2010). Identification of a tri-iron(III), tri-citrate complex in the xylem sap of iron-deficient tomato resupplied with iron: New insights into plant iron long-distance transport. Plant Cell Physiol. 51, 91-102. doi: 10.1093/pcp/pcp170

Sarkar, A. N., and Jones, R. G. W. (1982) Effect of rhizosphere $\mathrm{pH}$ on the availability and uptake of $\mathrm{Fe}, \mathrm{Mn}$ and Zn. Plant Soil 66, 361-372. doi: 10.1007/BF02183802

Schaaf, G., Erenoglu, B. E., and von Wirén, N. (2004). Physiological and biochemical characterization of metal-phytosiderophore transport in graminaceous species. Soil Sci. Plant Nutr. 50, 989-995. doi: 10.1080/00380768.2004.10408565

Shi, R. L., Weber, G., Koster, J., RezaHajirezaei, M., Zou, C., Zhang, F., et al. (2012). Senescence-induced iron mobilization in source leaves of barley (Hordeum vulgare) plants.
New Phytol. 195, 372-383. doi: 10.1111/j.1469-8137.2012.04165.x

Shi, R. L., Zhang, Y. Q., Chen, X. P., Sun, Q. P., Zhang, F. S., Römheld, V., et al. (2010). Influence of long-term nitrogen fertilization on micronutrient density in grain of winter wheat (Triticum aestivum L.) J. Cereal Sci. 51, 165-170. doi: 10.1016/j.jcs.2009.11.008

Stein, A. J., Nestel, P., Meenakshi, J., Qaim, M., Sachdev, H., and Bhutta, Z. A. (2007). Plant breeding to control zinc deficiency in India: how cost-effective is biofortification? Public Health Nutr. 10, 492-501. doi: $10.1017 /$ S1368980007223857

Takahashi, M., Terada, Y., Nakai, I., Nakanishi, H., Yoshimura, E., Mori, S., et al. (2003). Role of nicotianamine in the intracellular delivery of metals and plant reproductive development. Plant Cell 15, 1263-1280. doi: 10.1105/tpc.010256

Uauy, C., Distelfeld, A., Fahima, T., Blechl, A., and Dubcovsky, J. (2006). A NAC gene regulating senescence improves grain protein, zinc, and iron content in wheat. Science 314, 1298-1301. doi: 10.1126/science. 1133649

von Wirén, N., Klair, S., Bansal, S., Briat, J. F., Khodr, H., Shioiri, T., et al. (1999). Nicotianamine chelates both Fe-III and Fe-II. Implications for metal transport in plants. Plant Physiol. 119, 1107-1114. doi: 10.1104/pp.119.3.1107

Weibull, J., Ronquist, F., and Brishammar, S. (1990). Free amino-acid composition of leaf exudates and phloem sap - a comparative study in oats and barley. Plant Physiol. 92, 222-226. doi: 10.1104/pp.92.1.222

White, P. J., and Broadley, M. R. (2005). Biofortifying crops with essential mineral elements. Trends
Plant Sci. 10, 586-593. doi: 10.1016/j.tplants.2005.10.001

White, P. J., and Broadley, M. R. (2009). Biofortification of crops with seven mineral elements often lacking in human diets - iron, zinc, copper, calcium, magnesium, selenium and iodine. New Phytol. 182, 49-84. doi: 10.1111/j.1469-8137.2008.02738.x

WHO. (2002). The World Health Report 2002. Reducing Risks, Promoting Healthy Life. Geneva: World Health Organization.

Wiedemuth, K., Müller, J., Kahlau, A., Amme, S., Mock, H. P., Grzam, A., et al. (2005). Successive maturation and senescence of individual leaves during barley whole plant ontogeny reveals temporal and spatial regulation of photosynthetic function in conjunction with $\mathrm{C}$ and $\mathrm{N}$ metabolism. J. Plant Physiol. 162, 1226-1236. doi: 10.1016/j.jplph.2005.01.010

Xue, Y. F., Yue, S. C., Zhang, Y. Q., Cui, Z. L., Chen, X. P., Yang, F. C., et al. (2012). Grain and shoot zinc accumulation in winter wheat affected by nitrogen management. Plant Soil 361, 153-163. doi: 10.1007/s11104012-1510-2

Zhang, C. D., Römheld, V., and Marschner, H. (1995). Retranslocation of iron from primary leaves of bean plants grown under iron deficiency. J. Plant Physiol. 146, 268-272. doi: 10.1016/S0176-1617(11)82052-3

Zhao, F. J., Su, Y. H., Dunham, S. J., Rakszegi, M., Bedo, Z., McGrath, S. P., et al. (2009). Variation in mineral micronutrient concentrations in grain of wheat lines of diverse origin. J. Cereal Sci. 49, 290-295. doi: 10.1016/j.jcs.2008.11.007

Zheng, L., Yamaji, N., Yokosho, K., and Ma, J. F. (2012). YSL16 is a phloem-localized transporter of the copper-nicotianamine complex that is responsible for copper distribution in rice. Plant Cell 24, 3767-3782. doi: 10.1105/tpc.112.103820

Zou, C., Shen, J., Zhang, F., Guo, S., Rengel, Z., and Tang, C. (2001). Impact of nitrogen form on iron uptake and distribution in maize seedlings in solution culture. Plant Soil 235, 143-149. doi: 10.1023/A:1011902320662

Conflict of Interest Statement: The authors declare that the research was conducted in the absence of any commercial or financial relationships that could be construed as a potential conflict of interest.

Received: 22 February 2013; paper pending published: 19 March 2013; accepted: 29 July 2013; published online: 16 August 2013.

Citation: Barunawati N, Hettwer Giehl RF, Bauer B and von Wirén N (2013) The influence of inorganic nitrogen fertilizer forms on micronutrient retranslocation and accumulation in grains of winter wheat. Front. Plant Sci. 4:320. doi: 10.3389/fpls.2013.00320

This article was submitted to Plant Nutrition, a section of the journal Frontiers in Plant Science.

Copyright (๑ 2013 Barunawati, Hettwer Giehl, Bauer and von Wirén. This is an open-access article distributed under the terms of the Creative Commons Attribution License (CC BY). The use, distribution or reproduction in other forums is permitted, provided the original author(s) or licensor are credited and that the original publication in this journal is cited, in accordance with accepted academic practice. No use, distribution or reproduction is permitted which does not comply with these terms. 


\section{APPENDIX}

Table A1 | Two-Way analysis of variance (ANOVA) of the effects of $\mathbf{N}$ fertilization, leaf developmental stage and their interactions on response variables of field-grown winter wheat (Triticum aestivum cv. Akteur).

\begin{tabular}{llrl}
\hline & $\begin{array}{l}\text { N } \\
\text { fertilization }\end{array}$ & $\begin{array}{l}\text { Leaf dev. } \\
\text { stage }^{\mathbf{a}}\end{array}$ & $\begin{array}{l}\text { N fertil. } \times \text { leaf } \\
\text { dev. stage }\end{array}$ \\
\hline N concentration of flag leaves & 0.879 & $<0.001$ & 0.573 \\
Fe concentration of flag leaves & 0.404 & 0.004 & 0.106 \\
Zn concentration of flag leaves & 0.466 & $<0.001$ & 0.856 \\
Cu concentration of flag leaves & 0.419 & $<0.001$ & 0.160 \\
Fe concentration in grains & 0.357 & 0.032 & 0.531 \\
Zn concentration in grains & 0.566 & 0.186 & 0.787 \\
Cu concentration in grains & 0.619 & 0.003 & 0.003 \\
\hline
\end{tabular}

The F-value probabilities at 95\% confidence are indicated.

${ }^{a}$ Refers to the developmental stage of either flag leaves (green or senescent) or grains (immature or mature).
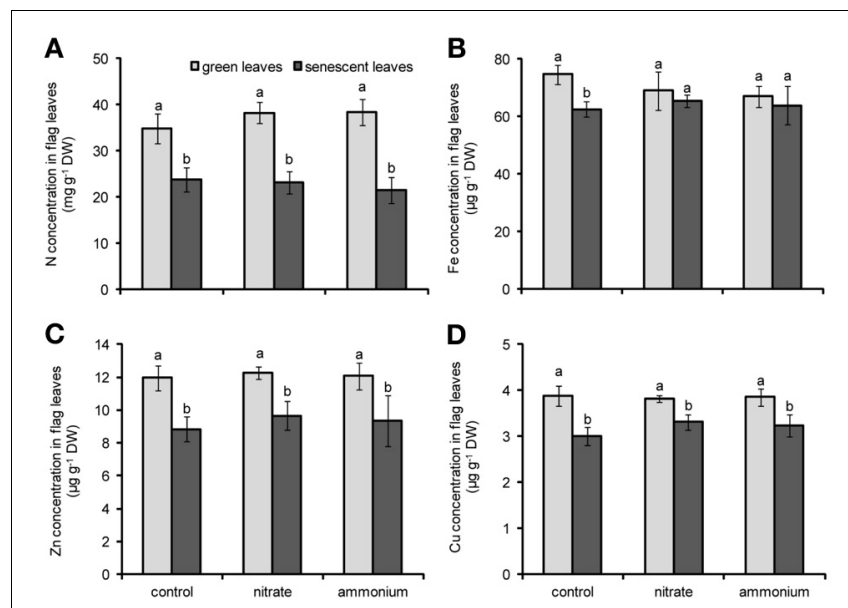

FIGURE A1 | Concentrations of N (A), Fe (B), Zn (C), and Cu (D) in flag leaves of winter wheat as affected by nitrate- or ammonium-based fertilization ( $80 \mathbf{~ k g ~ N ~ h a}^{-\mathbf{1}}$ ) at anthesis (EC65). Bars represent the means of 4 independent replicates $\pm S D$, and 4 plants per replicate. Means followed by different letters indicate significant differences between treatments according to Two-Way ANOVA followed by Tukey's test $(P \leq 0.05)$.
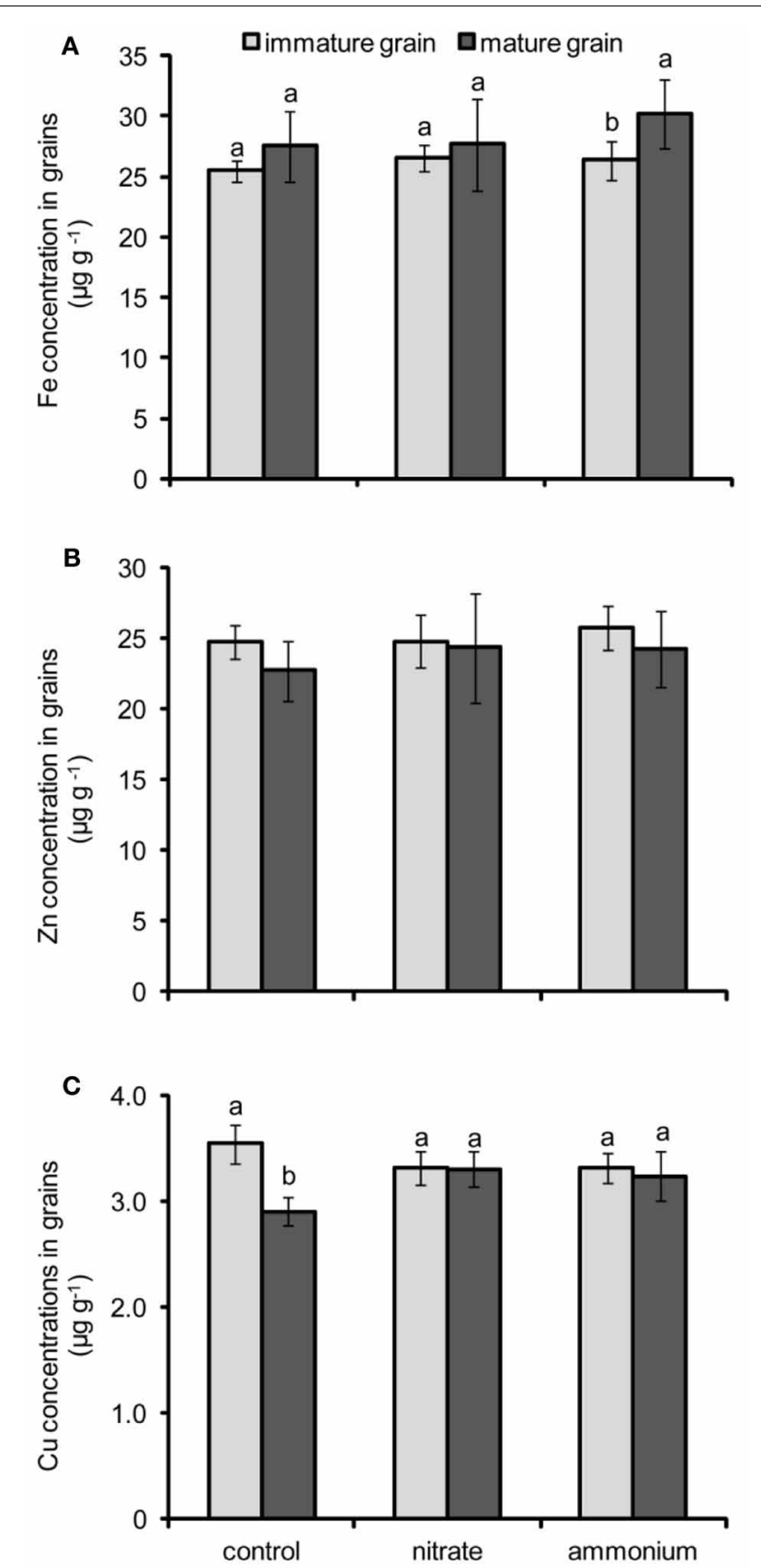

FIGURE A2 | Concentrations of $\mathrm{Fe}(\mathrm{A}), \mathrm{Zn}(\mathrm{B})$, and $\mathrm{Cu}(\mathrm{C})$ in grains of winter wheat as affected by nitrate- or ammonium-based fertilization (80 $\mathbf{~ k g ~ N ~ h a}{ }^{-1}$ ) at anthesis (EC65). Bars represent the means of 4 independent replicates $\pm S D$, and 4 plants per replicate. Means followed by different letters indicate significant differences between treatments according to Two-Way ANOVA followed by Tukey's test $(P \leq 0.05)$. The absence of letters (B) indicates no significant difference between treatments or their interactions according to Two-Way ANOVA. 